Red deer (Cervus elaphus L.) - the first milestone in antler development

Jelen obični (Cervus elaphus L.) - prva prekretnica razvoja rogovlja

Degmečić, D., Florijančić, T.

Poljoprivreda/Agriculture

ISSN: $1848-8080$ (Online)

ISSN: 1330-7142 (Print)

http://dx.doi.org/10.18047/poljo.24.1.8

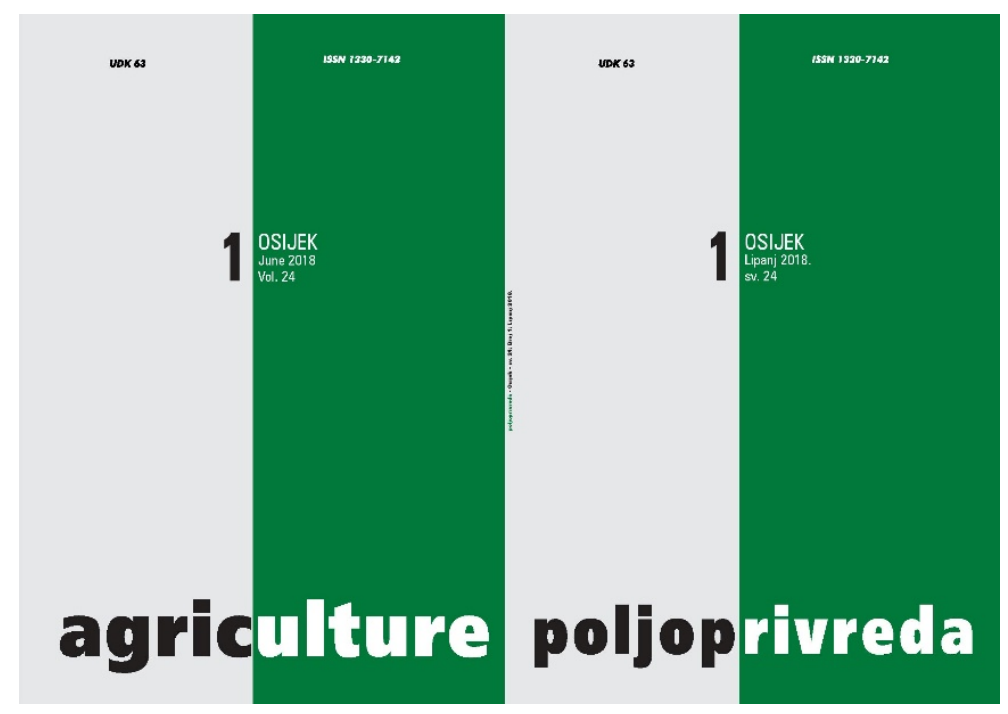

Poljoprivredni fakultet u Osijeku, Poljoprivredni institut Osijek Faculty of Agriculture in Osijek, Agricultural Institute Osijek 
ISSN $1330-7142$

UDK: 639.111.1:637.64

DOI: $10.18047 /$ poljo.24.1.8

\title{
RED DEER (Cervus elaphus L.) - THE FIRST MILESTONE IN ANTLER DEVELOPMENT
}

Degmečić, D. ${ }^{(1)}$, Florijančić, $T^{(2)}$

Original scientific paper

Izvorni znanstveni članak

\begin{abstract}
SUMMARY
Selection of males is based on two main parameters, degree of physical development (body weight) and the stage of secondary sexual characteristic development - antlers. Antlers can be characterized as a weapon which reflects the age, body weight and physiological condition. In particular, antler development is an indicator for selection of yearlings and young males too. Selection in age class "young males" (age 3-5 years) is crucial for managing male side of red deer population. In this age class young males require a lot of energy because they experience, both skeletal and physical development. In this age class it is important to mention that important elements of antlers appear - tines and possible royal. The research was conducted in the Baranja Danube area from the fenced unit of the hunting area in the same nutritional and habitat conditions. Cast antlers of 13 males were measured during their life (individual approach). After the data processing special attention was given to the "young males" age class. Trend of growth for all the observed parameters appeared. What occurred is the so-called first significant "jump - milestone" of antler development. Significant development of antlers in young males appear in the fifth year of their life when the young males reach the required physical and skeletal development. Thus, development of antlers can't jeopardize parallel operations of other body processes.
\end{abstract}

Key-words: red deer, young males, antlers, selection, Baranja, Croatia

\section{INTRODUCTION}

Deer antlers (Cervidae family) are an example of fast growing bones and the only bone formation in mammals, capable of complete regeneration. Males of all species within the deer family (Cervidae) grow antlers, except for the genus Rangifer, where both males and females grow them. Each year the antlers are discarded and each year a set of new antlers grow. This growth cycle is closely associated with the reproductive cycle, hormonal processes and photoperiodism (Bubenik, 1990; Kierdorf and Bartoš, 1999; Bauman et al., 2000; Bubenik and Hundertmark, 2002; Crowley et al., 2004.). On the other hand antler size in cervids is known to be influenced by age, nutrition, health status and genetic factors (Wolfe, 1983). Beside the biological value of the antlers, economic importance of deer antlers is equally vital. Wild ungulates have been hunted for centuries no matter whether for food or sport.

Wildlife management uses hunting as a tool to eliminate the possible annual surplus of animals in the population. Wildlife management should recognize the impacts of hunting beyond simply reducing population densities (Apollonio et al., 2017). Wildlife populations are managed on the basis of sustainable development, so it is necessary to remove a certain number of animals from all sex and age classes. Variables increasing the probability that selective hunting for male mammals with large horns, tusks or antlers will lead to evolutionary changes in the size of the horns, tusks or antlers include aspects of a species' biology but also many variables under the control of wildlife managers (Festa-Bianchet, 2016). The subject of this paper is males, namely the selection of young males. Trophy hunting represents one form of selective harvesting that has been traditionally implemented in wild cervids. This harvesting regime is a non-random process whereby humans select individuals are to be removed from a population based on 1 or several phenotypic traits (Pozo et al., 2016). The aim of this paper should point to significant difference in the parameters of red deer antlers

(1) Assist. Prof. Dražen Degmečić - Hrvatske šume d.o.o. Zagreb/Uprava šuma Podružnica Osijek, Julija Benešića 1, 31000 Osijek, Croatia, (2) Prof. Dr. Tihomir Florijančić (tflorijanc@pfos.hr) - Josip Juraj Strossmayer University of Osijek, Faculty of Agriculture in Osijek, Vladimira Preloga 1, 31000 Osijek, Croatia 
in young males, and between the second, third and fourth heads at red deer, as well as differences that can bring significant gain in the value of red deer antlers at maturity when the greatest financial impact from wildlife management is present. As the title suggests, if it is not sure whether observed animal is for selection it is better to wait for the first milestone in antler development.

\section{MATERIAL AND METHODS}

The study was conducted in the Baranja Danube area (GPS 45.724270, 18.863572). The research area is located in the north-eastern part of Croatia, just by the Hungarian and Serbian border. It is the swampy riverbed of the Danube River. The research material consisted of cast antler branches of 13 males. Every year during the life of the 13 males, the branches of cast antlers were collected and measured. In this way it was possible to monitor the growth and development of antlers, from each individual. The mentioned males were labelled with their ear tags as calves. With this method (ear tagging) it was possible to accurately determine the age of individuals, each year. The males were in the enclosed part of the open hunting ground, in the same nutritional and habitat conditions, which facilitated their monitoring and finding cast antler branches. The measurement was done in the way prescribed by the "International Hunting and Game Conservation
Council (CIC)" - formula for assessing the trophies of the Red deer (Frković, 2017). The total mass of antlers is made up of antlers and skulls. Given that there is no skull in the cast antlers, we have added one kilogram to the weight of the antlers as substitute for skull (approximate value). This added value of one kilogram is equal for all pairs of cast antlers so that if there is an error it is systematic measurement error of samples (Pranjić, 1990). It is also equal to all samples and has no significant influence on the final conclusions. Likewise, the range is also defined as such, the value of three points were given to all the measured pairs of cast antlers. After data processing, special attention was given to the age group "young males" aged 3-5 years. The obtained values of the traits were compared with each other for hunting years. The data is processed in the IBM SPSS Statistics 20 software package.

\section{RESULTS AND DISCUSSION}

Antler parameters as CIC value, antler mass, total length of antler branch and length of the third antler tine are shown in Table 1. These traits are important when selection of red deer males is considered. Possible visual assessments in nature, based on the experience of individual hunter when observing wild animals and their core management characteristics are alsi important (Degmečić, 2009).

Table 1. Overview of mean, minimal and maximal values of measured antler traits during the life of the observed red stags Tablica 1. Pregled srednjih, minimalnih i maksimalnih vrijednosti mjerenih parametara rogovlja kroz godine života mužjaka jelena običnog

\begin{tabular}{|c|c|c|c|c|c|c|c|c|c|c|}
\hline $\begin{array}{l}\text { Age/Year Mark } \\
\text { Dob/Oznaka za godinu* }\end{array}$ & $3 / B$ & $4 / C$ & $5 / D$ & $6 / E$ & $7 / F$ & $8 / G$ & $9 / \mathrm{H}$ & $10 / 1$ & $11 / \mathrm{J}$ & $12 / \mathrm{K}$ \\
\hline \multicolumn{11}{|c|}{ CIC-value / CIC-vrijednost } \\
\hline $\begin{array}{l}\text { Mean } \\
\text { Srednja vrijednost }\end{array}$ & 135.40 & 150.72 & 182.55 & 195.42 & 208.90 & 220.24 & 222.28 & 222.31 & 222.00 & 219.00 \\
\hline $\begin{array}{l}\text { Minimum } \\
\text { Minimum }\end{array}$ & 124.00 & 140.00 & 172.00 & 186.00 & 197.00 & 198.00 & 210.00 & 220.00 & 222.00 & 219.00 \\
\hline $\begin{array}{l}\text { Maximum } \\
\text { Maksimum }\end{array}$ & 145.00 & 159.00 & 190.00 & 206.00 & 218.00 & 243.00 & 239.00 & 225.00 & 222.00 & 219.00 \\
\hline \multicolumn{11}{|c|}{ Antler mass $(\mathrm{kg}) /$ Masa rogovlja $(\mathrm{kg})$} \\
\hline $\begin{array}{l}\text { Mean } \\
\text { Srednja vrijednost }\end{array}$ & 2.35 & 3.58 & 5.82 & 7.17 & 7.88 & 9.10 & 9.44 & 9.83 & 10.12 & 10.24 \\
\hline $\begin{array}{l}\text { Minimum } \\
\text { Minimum }\end{array}$ & 1.90 & 2.90 & 5.10 & 6.50 & 6.60 & 6.40 & 7.70 & 9.00 & 10.10 & 10.20 \\
\hline $\begin{array}{l}\text { Maximum } \\
\text { Maksimum }\end{array}$ & 2.80 & 4.10 & 6.90 & 7.60 & 9.00 & 12.80 & 12.30 & 10.80 & 10.14 & 10.28 \\
\hline \multicolumn{11}{|c|}{ Antler lenght $(\mathrm{cm}) /$ Duljina grane $(\mathrm{cm})$} \\
\hline $\begin{array}{l}\text { Mean } \\
\text { Srednja vrijednost }\end{array}$ & 68.26 & 75.62 & 92.74 & 99.99 & 103.51 & 109.25 & 111.92 & 111.48 & 109.65 & 112.60 \\
\hline $\begin{array}{l}\text { Minimum } \\
\text { Minimum }\end{array}$ & 56.90 & 72.30 & 88.50 & 96.50 & 96.20 & 98.80 & 105.60 & 110.10 & 109.60 & 112.60 \\
\hline $\begin{array}{l}\text { Maximum } \\
\text { Maksimum }\end{array}$ & 76.60 & 79.10 & 97.60 & 105.90 & 107.60 & 119.10 & 116.20 & 112.30 & 109.70 & 112.60 \\
\hline \multicolumn{11}{|c|}{ Third tine lenght (cm) / Duljina srednjaka (cm) } \\
\hline $\begin{array}{l}\text { Mean } \\
\text { Srednja vrijednost }\end{array}$ & 26.48 & 26.87 & 38.61 & 40.57 & 41.19 & 41.59 & 42.89 & 46.33 & 40.80 & 37.70 \\
\hline $\begin{array}{l}\text { Minimum } \\
\text { Minimum }\end{array}$ & 21.40 & 24.80 & 32.60 & 38.10 & 33.90 & 32.40 & 30.20 & 36.20 & 40.80 & 37.70 \\
\hline $\begin{array}{l}\text { Maximum } \\
\text { Maksimum }\end{array}$ & 31.90 & 30.00 & 44.30 & 42.70 & 51.60 & 55.10 & 59.00 & 57.50 & 40.80 & 37.70 \\
\hline
\end{tabular}

*Each year is marked with a capital letter. This letter will be used for comparison in statistical tests / Svaka godina označena je velikim slovom $i$ korištena je kod usporedbe statističkim testovima 
Although relationship between antler characteristics and age, nutrition, population density, adult sex ratio, mass at birth have been reported for harvested and culled deer (Clutton-Brock et al., 1982; Solberg and Saether, 1994; Smith, 1998), it is important to point out the first milestone in antler growth for wildlife management. At wildlife management everything happens once in a year so this kind of knowledge can significantly shorten the way and enable earlier achievement of the management goals. Statistical data processing was performed for the measured traits shown in Table 1. A comparison was made between the measured antler traits through the years. The objective of such analysis was to acquire the moment (year of life) when the measured parameters make a significant difference (jump) in value compared to the previous year. From Table 2 it is clearly visible that all the measured parameters (CIC-value, ant- ler mass, length of antlers and length of the third tine) are significantly increased from the fourth to fifth year of life. The age class of young males constitutes males three, four and five years old. In this age class there is a trend of growth of all the observed parameters as well as high degree of mutual association of the observed parameters (linear) growth (Degmečić, 2009). But this analysis shows that when we look at the males in this age class, we have to take into account the fact that at the age of five there is a significant difference in the growth of the important antler traits compared to the previous two years of the observed class. Features such as the length of the branch, the length of the third tine and the total $\mathrm{CIC}$ value of antlers are the basic elements according to which the breeder decides whether the animal will remain in the further breeding process or it will be included in the selection cull.

Table 2. Overview of a statistical significant comparison of the mean antler values of the measured parameters obtained over the period of the research $(\mathrm{N}=13)$

Tablica 2. Pregled razlika u mjerenim srednjim vrijednostima parametara odbačenoga rogovlja kroz godine života mužjaka jelena običnog $(N=13)$

\begin{tabular}{|c|c|c|c|c|c|c|c|c|c|c|}
\hline $\begin{array}{l}\text { Age / Year mark } \\
\text { Starost / Oznaka za godinu }\end{array}$ & $3 / B$ & $4 / C$ & $\begin{array}{c}5 / \\
D\end{array}$ & $\begin{array}{c}6 / \\
E\end{array}$ & $\begin{array}{l}7 / \\
F\end{array}$ & $\begin{array}{c}8 / \\
G\end{array}$ & $\begin{array}{l}9 / \\
\mathrm{H}\end{array}$ & $\begin{array}{c}10 / \\
1\end{array}$ & $\begin{array}{l}11 \\
/ \mathrm{J}\end{array}$ & $\begin{array}{c}12 / \\
K\end{array}$ \\
\hline $\begin{array}{l}\text { CIC - value } \\
\text { CIC - vrijednost }\end{array}$ & & & $B C$ & $B C$ & $B C D$ & $\mathrm{BCDE}$ & BCDE & BCDE & & \\
\hline $\begin{array}{l}\text { Antler mass }(\mathrm{kg}) \\
\text { Masa rogovlja }(\mathrm{kg})\end{array}$ & & & $B C$ & $B C$ & $B C D$ & $\mathrm{BCDE}$ & BCDE & BCDE & & \\
\hline $\begin{array}{l}\text { Lenght of antler }(\mathrm{cm}) \\
\text { Duljina grane }(\mathrm{cm})\end{array}$ & & & $B C$ & $B C$ & $\mathrm{BCD}$ & $\mathrm{BCDE}$ & BCDE & BCDE & & \\
\hline $\begin{array}{l}\text { Lenght of the third tine }(\mathrm{cm}) \\
\text { Duljina srednjaka }(\mathrm{cm})\end{array}$ & & & $B C$ & $B C$ & BC & $B C$ & BC & BC & & \\
\hline
\end{tabular}

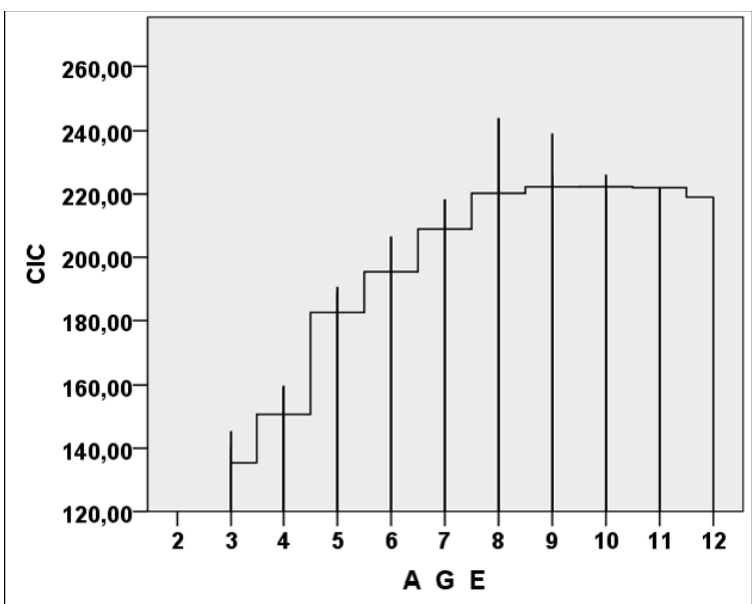

Figure 1. Mean of CIC value of the cast antlers through the years of life of the observed red deer stags

Slika 1. CIC vrijednosti odbačenoga rogovlja kroz godine života promatranih mužjaka jelena običnog

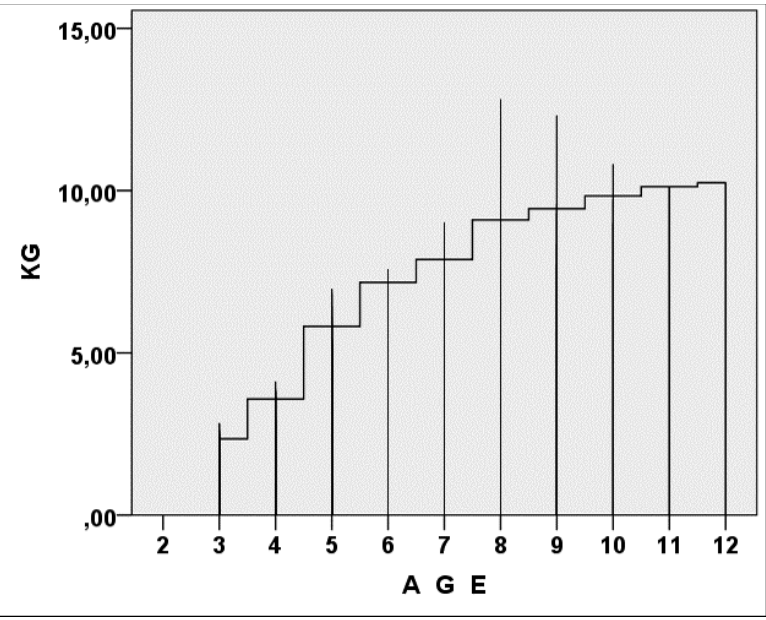

Figure 2. Mean of mass $(\mathrm{kg})$ value of the cast antlers through the life years of the red deer stags

Slika 2. Srednja vrijednost mase $(\mathrm{kg})$ odbačenoga rogovlja kroz godine života mužjaka jelena običnog 


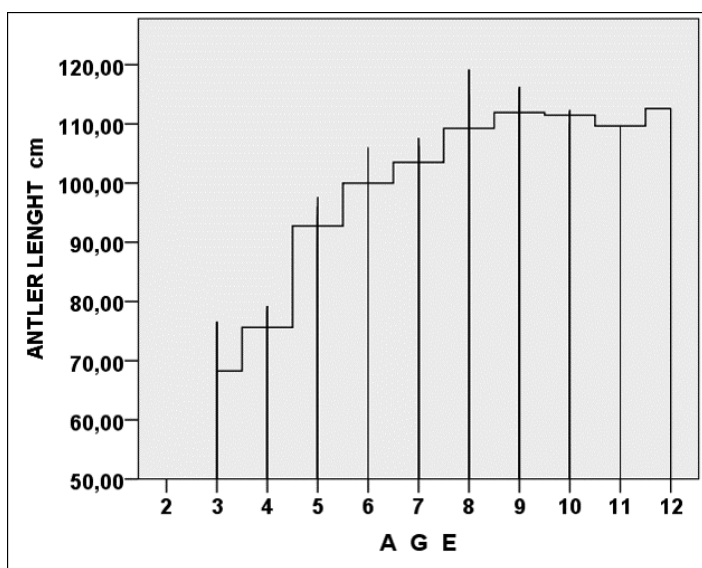

Figure 3. Antler length mean $(\mathrm{cm})$ of the cast antlers through the life years of the observed red deer stags

Slika 3. Srednje vrijednosti duljine grana $(\mathrm{cm})$ odbačenoga rogovlja kroz godine života mužjaka jelena običnog

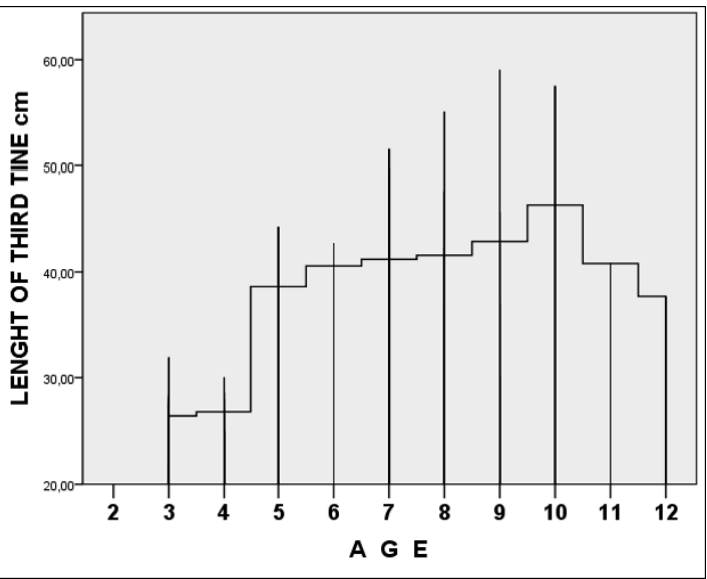

Figure 4. Mean of the length of the third tine $(\mathrm{cm})$ of the cast antlers through the life years of the observed red deer stags

Slika 4. Srednjih vrijednosti duljine parožaka srednjaka (cm) odbačenoga rogovlja kroz godine života promatranih mužjaka jelena običnog

From Table 1 (comparison of column means) (significance level 0.05) and Figures 1 to 4 it is clear and visible (interpolation step line) that the first significant change in the growth and development of antlers occurs in the fifth year of red deer stag. Figures 1-4 (CIC-value, antler mass, antler length and length of third tine), show clearly the highest difference (step) between the fourth and fifth year of the young red stags. Significant changes also occur later in life, for example in seventh year, etc., however the first milestone, as this paper shows, appear from the fourth to the fifth year of red stag life. Brna et al. (1993), during the researches related to the comparison of the results of breeding in free nature and farm, got the first major difference in CIC value (28 CIC points) in the fifth year of stags life. Male elk, investigated in Wayoming related to causes of death during winter and antler mass, showed significant jump from four year old stag and five year old stag - almost
2 kilograms (Smith, 1998). Wolfe (1983) was researching connection between antler development and age in Wapiti, and among other things, determined that antler length and antler weight were significantly greater when the difference between fourth year and fifth year was considered. Almost all parameters grow together with the age up to 12-14 years. After this period the parameters usually start to decrease slowly (Bokor et al., 2013). Previous studies of Cervidae have, in many cases, resulted in animals that should reach certain values (thresholds) to obtain or significantly develop a certain ability or characteristic. The calves should reach $40 \mathrm{~kg}$ of net body weight - threshold to successfully survive the winter (Clutton-Brock and Coulson, 2003; Langvatn et al., 2004). The females should reach $60 \mathrm{~kg}$ of net body weight in order to enter the reproduction cycle (Clutton-Brock et al., 1982). Pedicle development and then the development of the first antlers are related to a certain threshold of the body mass (Suttie et al., 1983). Equally, researches of many authors have shown the correlation between development of antler and body mass (Degmečić, 2009). Thus, it has been shown that the growth and development of the body manage many processes in the organism of Cervidae.

\section{CONCLUSION}

Selection in the age class of young males $(3-5$ years old) is very important for the future formation of the male part of the red deer population in their economic maturity ( 9 and more years old). In these few years, young males require a lot of energy for their skeletal and physical development (Simpson, 1993). Equally important in this age class is architecture formation of antlers (Bubenik, 1982). Added to this the conclusion that within this age class there is the first milestone in antler development, it is clear that selection in this age class becomes important. That first milestone in antler development should separate the five-year-old males from those in the third and fourth year when selection is considered. The purpose of this paper is to warn that decision making tools about the selection of red stags in the fifth year should be different from the decision making tools for red stags tree or four year old. Otherwise it can have significant consequences for the mature age class. It is necessary to continue the research in the direction of body mass balance and development of the red stags, precisely in that fifth year in order to be able to confirm certain disagreement about the possible connection. The devil is in the detail (Clutton-Brock and Coulson, 2003).

\section{REFERENCES}

1. Apollonio, M., Belkin, V. V., Borkowski, J., Borodin, 0. I., Borowik, T., Cagnacci, F \& Yanuta, G. (2017). Challenges and science-based implications for modern management and conservation of European ungulate populations. Mammal Research 62(3), 209-217. https:// doi.org/10.1007/s13364-017-0321-5 
2. Bauman, J. P., Jenks, J. J., \& Roddy, D. E. (2000). Bull American Elk, Cervus elaphus, mortality resulting from locked antlers during spring sparring. The Canadian Field-Naturalist, 114(1), 144-147.

3. Bokor, J., Bokor, A., Nagy, J., Horn, P., \& Nagy, I. (2013). Summary of Comments on Analysis of Hungarian red deer trophies by means of Principal component analysis in two different counties. Journal of Central European Agriculture, 14(1), 452-466. https://doi.org/10.5513/ JCEA01/14.1.1220

4. Brna, J., Nikolandić, Đ., \& Urošević, B. (1993). Porast trofejne vrijednosti rogova jelena u ograđenim uzgajalištima. Šumarski list, 117(3-5), 109-121.

5. Bubenik, A. B. (1982): The behavioural aspects of antlerogenesis. Antler development in cervidae. Caesar Kleberg Wildlife Research Institute, Kingsville, USA.

6. Bubenik, G. A. (1990): Neuroendocrine regulation of the antler cycle. In G.A. Bubenik \& A., B. Bubenik (Eds.), Horns, pronghorns and antlers - evolution, morphology, physiology and social significance (pp 265-397), Springer - Verlag. https://doi.org/10.1007/978-1-46138966-8

7. Bubenik, G. A., \& Hundertmark, K. J. (2002). Accessory antlers in male Cervidae. Zeitschrift für Jagdwissenschaft, 48(1), 10-21. https://doi.org/10.1007/BF02285353

8. Clutton-Brock, T. H., \& Coulson, T. (2003). Comparative ungulate dynamics: the devil is in detail. In R., M. Sibly, J. Hone \& T. H. Clutton - Brock, Wildlife population growth rates (pp 249-270. Cambridge University Press.

9. Clutton-Brock, T. H., Guinness, F. E. \& Albon, S. D. (1982). Red deer: behaviour and ecology of two sexes. The University of Chicago Press, Chicago, Illinois,

10. Crowley, V., Barrell, G. K., \& Keeley, M. J. (2004). A split night photoperiod does not mimic effects of a long - day photoperiod on growth in weaner red deer stags. In C. Morrow (Ed.) Proceedings of the New Zealand society of animal production 64 (pp. 63-66). Hamilton, New Zealand: New Zealand Society of Animal Production.

11. Degmečić, D. (2009). Model sustava za potporu pri uzgoju jelena običnog (Cervus elaphus, L.) u slobodnoj prirodi. Doktorski rad, Osijek.

12. Festa-Bianchet, M. (2016). When does selective hunting select, how can we tell, and what should we do about it?
Mammal review, 47(1), 76-81. https://doi.org/10.1111/ mam.12078

13. Frković, A. (2017). Priručnik za ocjenjivanje lovačkih trofeja. Hrvatski lovački savez, Zagreb.

14. Kierdorf, U., \& Bartoš, L. (1999). Treatment of the growing pedicle with retinoic acid increased the size of first antlers in fallow deer (Dama dama, L.). Comparative Biochemistry and Physiology - Part C: Toxicology \& Pharmacology, 124(1), 7-9. https://doi.org/10.1016/ S0742-8413(99)00038-9

15. Langvatn, R., Mysterud, A., Stenseth, N. C., \& Yoccoz, N. G. (2004). Timing and synchrony of ovulation in red deer constrained by short northern summers. The American naturalist, 163(5), 763-772. https://doi. org $/ 10.1086 / 383594$

16. Pozo, A. R., Schindler, S., Cubaynes S., Cusak, J. J., Coulson, T., \& Malo, A. F. (2016). Modelling the impact of Selective Harvesting on Red Deer Antlers. The Journal of Wildlife Management, 80(6), 978-989. https://doi. org/10.1002/jwmg.21089

17. Pranjić, A. (1990). Šumarska biometrika. Sveučilišna naklada Liber, Zagreb, Croatia.

18. Simpson, R. K. (1993). Finishing of red deer. A salute to world deer farming. In I. Woodhouse (Ed.), Proceedings of the First World Deer Congress (pp 63-68). Christchurch, New Zealand: New Zealand Deer Farmers Association.

19. Smith, B. L. (1998). Antler size and winter mortality of elk: Effects of environment, birth year and parasites, Journal of Mammalogy, 79(3): 1038-1044. https://doi. org/10.2307/1383113

20. Solberg, E. J., \& Saether, B. E. (1994). Male traits as lifehistory variables: annual variation in body mass and antler size in moose (Alces alces), Journal of Mammalogy, 75(4), 1069-1079. https://doi.org/10.2307/1382491

21. Suttie, J. M., Goodall, E. D., Pennie, K., \& Kay, R. N. B. (1983). Winter food restriction and summer compensation in red deer stags (Cervus elaphus). British Journal of Nutrition, 50(3), 737-747. https://doi.org/10.1079/ BJN19830145

22. Wolfe, G. J. (1983). The relationship between age and antler development in wapiti. Antler development in cervidae. Caesar Kleberg Wildlife Research Institute, Texas A \& I University, Kingsville, USA. 


\section{JELEN OBIČNI (Cervus elaphus L.) - PRVA PREKRETNICA RAZVOJA ROGOVLJA}

\section{SAŽETAK}

Odabir kod mužjaka temelji se na dvama glavnim parametrima, stupnju tjelesnoga razvoja (tjelesna masa) $i$ stupnju razvoja sekundarne spolne osobine - grana rogovlja. Rogovlje se može okarakterizirati kao oružje na kojemu se odražava dob, tjelesna masa i fiziološko stanje. Stupanj je razvoja rogovlja standard odabira kod grla tijekom rasta i razvoja, posebno kod godišnjaka, ali i mladih mužjaka. Dobni razred „mladi mužjaci”, starosti 3-5 godina presudan je prilikom odabira kod muškoga dijela populacije jelenske divljači. U tome dobnome razredu mladi mužjaci zahtijevaju dosta energije zbog svoga i skeletnoga i tjelesnoga razvoja. Jednako tako se u tome dobnome razredu pojavljuju važni elementi grane rogovlja, parožak srednjak i jednostruko ili višestruko razdvajanje završetka grane. Istraživanje je obavljeno na području baranjskoga Podunavlja, u ograđenome dijelu lovišta, u kojem su isti hranidbeni i stanišni uvjeti. Obrađene su odbačene grane 13 mužjaka tijekom godina njihovoga života iz ograđene jedinice dijela lovišta (individualni pristup). Nakon obrade podataka, posebna se pažnja poklonila dobnome razredu „mladi mužjaci”. Utvrđeno je kako je u tome dobnome razredu prisutan trend rasta svih promatranih odlika. No, jednako je tako utvrđena i dob kada dolazi do prvoga tzv. „skoka“, odnosno značajne razlike u razvoju rogovlja u odnosu na prethodnu godinu života jedinke. Značajan razvoj rogovlja kod mladih mužjaka događa se u petoj godini života, kada mladi mužjaci dostignu potreban tjelesni i skeletni razvoj te razvojem rogovlja ne mogu ugroziti usporedo odvijanje ostalih tjelesnih procesa u organizmu.

Ključne riječi: jelen obični, mladi mužjaci, rogovlje, odabir, Baranja, Hrvatska

(Received on 6 April 2018; accepted on 18 May 2018 - Primljeno 06. travnja 2018.; prihvaćeno 18. svibnja 2018.) 